\title{
Retorika Dakwah Ustadz Handy Bonny
}

\author{
Asep Saeful Millah ${ }^{1 *}$, Dindin Solahudin ${ }^{1}, \&$ Bahrudin $^{2}$ \\ ${ }^{1}$ Jurusan Pengembangan Masyarakat Islam, Fakultas Dakwah dan Komunikasi, UIN Sunan \\ Gunung Djati, Bandung \\ ${ }^{2} J u r u s a n$ Komunikasi dan Penyiaran Islam, Fakultas Dakwah dan Komunikasi, UIN Sunan \\ Gunung Djati, Bandung \\ *Email : Asepsm64@mail.com
}

\begin{abstract}
ABSTRAK
Tulisan ini bertujuan untuk mengetahui Gaya Bahasa, diksi, intonasi, dan gagasan retorika yang dikemukakan Ustadz Handy Bonny. Metode penelitian menggunakan metode deskriptif studi kasus. Metode ini dipilih untuk mendapatkan hal yang objektif dan representative. Sumber data primer dalam penelitian ini adalah Ustadz Handy Bonny yang didapatkan dari rekaman video ceramah di youtube. Kemudian sumber data skunder didapatkan dari media tv, internet dan lainnya. Analisis data dengan analisis kualitatif. Hasil penelitian ini menunjukkan retorika dakwah Ustadz Handy Bonny yang mampu memikat jamaah yang mendengarkan ceramahnya. Beliau menggunakan banyak gaya bahasa, diksi yang sederhana, intonasi yang bagus, dan memiliki gagasan retorika yang khas.
\end{abstract}

Kata Kunci : Retorika Dakwah; Gaya Bahasa; Gagasan Retorika; Ustadz Handy Bonny

\section{ABSTRACT}

This paper aims to find out the style of language, diction, intonation, and rhetorical ideas expressed by Ustadz. Handy Bonny. The research method uses a descriptive case study method. This method was chosen to get an objective and representative thing. The primary data source in this study was Ustadz. Handy Bonny which was obtained from video lectures on youtube. Then secondary data sources are obtained from TV, internet and other media. Data analysis with qualitative analysis. The results of this study show the rhetoric of the preaching of Ustadz Handy Bonny that is able to lure the worshipers who listen to his lecture. He uses many styles of language, simple diction, good intonation, and has a distinctive rhetorical idea.

Keywords : Da'wah Rhetoric; Language style; Rhetorical Ideas; Ustadz. Handy Bonny 


\section{PENDAHULUAN}

Dakwah merupakan kegiatan menyeru, mengajak dan memanggil orang untuk beriman dan bertakwa kepada Allah Swt serta mengikuti sunnah Rasulullah Muhammad Saw. Dakwah dapat dilakukan dimana saja, tidak mesti di tempat tertentu asal disampaikan dengan akidah dan syariat Islam yang baik dan benar juga disampaikan dengan situasi kondisi yang dihadapi. Menurut Alwi Shihab, sebagaimana dikutip oleh Abzar (2015: 41) dakwah merupakan istilah teknis, disamping sebagai cara untuk memperteguh keimanan orang-orang yang telah Islam, pada dasarnya dakwah juga dipahami sebagai upaya mengimbau orang lain ke arahIslam.

Pada saat ini seni dalam berdakwah banyak dilakukan oleh mubaligh, baik menggunakan tulisan (kitabah) di internet, maupun lisan (khithabah) melalui audio visual dengan menggunakan bahasa komunikasi yang disampaikan oleh mubaligh. Berdakwah dengan menggunakan bahasa gaul atau bahasa yang ringan dapat diterima oleh para remaja sebagai alat komunikasi dalam menyampaikan dakwahnya. Kegiatan dakwah perlu memiliki unsur keindahan dan kenyamanan dalam mengolah isi pesan itu sendiri, yakni dengan menjaga keindahan penyampaian pesan menggunakan bahasa yang dimengerti oleh para remaja zaman modern ini.

Adapun cara penyampaian dakwah dikelompokkan menjadi tiga kategori, yakni dakwah bil-lisan, dakwah bil-hal, dakwah bil-qolam. Dakwah bil lisan, yaitu dakwah yang dilaksanakan melalui lisan, yang dilakukan antara lain dengan ceramah-ceramah, khutbah, diskusi, nasehat, dan lain-lain (Munir, 2008: 11).

Khitobah merupakan kegiatan dakwah dalam bentuk lisan. Kegiatan ini dapat diterima dengan baik oleh para mad'u apabila mubalighnya mengetahui situasi dan kondisi yang dihadapi. Karena setiap orang berbeda-beda, baik dari segi usia, tingkat keilmuan, dan juga sosial masyarakat. Mubaligh dituntut agar pandai dalam melaksanakan strategi dakwahnya.

Dakwah di era modern ini jelas memiliki banyak sekali tantangan. Salah satunya saja ialah pergaulan di kalangan remaja yang lebih menikmati kehidupan yang serba bebas dan lebih suka berkumpul dengan teman-temannya di jalanan, mall, dan tempat-tempat yang lainnya. Seorang mubaligh pun harus mampu merangkul dan diterima remaja dalam menyampaikan dakwahnya dengan cara datang kepada para remaja tersebut untuk mengingatkan kepada hal yang jauh lebih baik dari pada harus berkumpul di tempat itu.

Mubaligh dituntut untuk pandai dalam melaksanakan strategi dakwahnya. Kegagalan para mubaligh dalam menyampaikan pesan dakwahnya akan terjadi apabila kurangnya pemahaman ilmu dan juga kurang teliti dalam melaksanakan

strategi dakwahnya. Pesan dakwah yang di sampaikan secara lisan oleh mubaligh pun harus di kemas dengan sedemikian indah ini merupakan aktivitas yang sering digunakan dalam berinteraksi dengan mad'u. oleh sebab itu, seni 
berbicara

merupakan salah satu kapabilitas yang harus dimiliki para mubaligh dalam menyampaikan pesan dakwahnya atau sering disebut retorika.

Dalam hal ini retorika merupakan seni mempengaruhi orang lain melalui pesan tabligh, agar minat dari mad'u menigkat dalam mengikuti kajian dakwah. Retorika dakwah merupakan cabang dari ilmu komunikasi yang membahas bagaimana cara menyampaikan pesan terhadap orang lain melalui seni berbicara agar pesan dakwahnya dapat di sampaikan dengan baik.

Retorika menjadi modal utama da'i dalam berdakwah. Dalam hal ini retorika merupakan seni mempengaruhi orang lain agar mad'u dapat tertarik dalam mengikuti kajian dakwah. Retorika sebagai ilmu bicara sebenarnya diperlukan setiap orang. Bagi ahli komunikasi atau komunikator retorika adalah conditi sine quanon. (Rahmat, 2015: 2)

Dari fenomena di zaman sekarang seorang mubaligh dituntut untuk mengemas pesan-pesan tabligh seindah dan semenarik mungkin. Ini merupakan usaha dari seorang mubaligh dalam menyampaikan pesan dakwahnya dengan retorika dan juga ilmu pengetahuan yang memadai. Dengan begitu, dakwah akan mampu disampaikan dan dikemas dengan sangat baik sehingga dakwah akan efektif.

Diantara mubaligh yang mendapat respon yang baik dari kaum muda adalah Ustadz Handy Bonny. Sebenarnya nama asli beliau adalah Handy Mahmud dia adalah ustadz muda dan gaul yang dikenal baik dikalangan remaja di kota Bandung. Gaya beliau dalam berdakwah menggunakan bahasa yang gaul yang dikemas dengan sangat baik. dia dikenal sebagai Ustadz muda yang selalu menyampaikan dakwahnya dengan gaya yang mengikuti tren anak muda jaman sekarang'.

Handy Bonny berhasil mengembangkan dakwah pemuda di beberapa kota di Indonesia. Yakni di Pulau Jawa dan pula-pulau lainnya. Dahulu Handy Bonny keliling Indonesia dengan basic Event Organizer dan hanya bikin kemaksiatan. Namun sekarang ia keliling Indonesia untuk menebarkan kebaikan melalui dakwah.

Dari latar belakang masalah tersebut dapat dirumuskan beberapa masalah: bagaimana gaya bahasa Ustadz Handy Bonny? Bagaimana diksi dan inotanasi yang digunakan Ustadz Handy Bonny? Bagaimana penyampaian gagasan retorika dakwah Ustadz Handy Bonny?

Metode yang digunakan dalam penelitian ini adalah studi kasus. Yaitu eksplorasi mendalam dari sistem terikat. Misalnya kegiatan, acara, proses, dan individu berdasarkan pengumpulan data yang luas. Studi kasus adalah salah satu metode yang digunakan dalam penelitian deskriptif. Menurut Sukmadinata sebagaimana dikutip Mega Linarwati,et al (2016: 2) penelitian deskriptif adalah suatu bentuk penelititan yang di tunjukkan untuk mendeskripsikan fenomena- 
Retorika dakwah ustadz Handy Bonny

fenomena yang ada, baik fenomena alamiah maupun fenomena buatan manusia. Fenomena itu bisa berupa bentuk, aktivitas, karakteristik, perubahan, hubungan, kesamaan, dan perbedaan antara fenomena satu dengan yang lainnya.

Untuk mendapatkan data yang mendalam pada penelitian studi kasus, maka Peneliti menggunakan teknik wawancara, observasi, dan studi dokumenter yang kemudian dianalisis.

\section{LANDASAN TEORITIS}

Teori yang dijadikan landasan dalam penelitian ini adalah teori retorika dan teori dakwah. Retorika adalah seni berbicara yang baik, seni berpidato, dan mengarang dengan benar, teliti, jelas, dan kuat. Definisi retorika menurut Aristoteles adalah ilmu atau seni mengajak orang orang untuk terampil tutur yang efektif. Menurutnya, retorika merupakan sebuah tuturan yang efektif berisi kebenaran, disiapkan dan ditata secara ilmiah (Muhtadi, 2013: 51).

Sedangkan menurut Abdullah, (2009: 109) arti retorika adalah seni berpidato atau mengarang/membuat naskah denga baik. Dalam Webster's world college dictionary disebutkan bahwa retorika adalah "the art of speaking or writing with correctness, clearness and strength", yakni seni berpidato atau mengarang denga benar, teliti, jelas, dan kuat.

Retorika juga diartikan sebagai kesenian untuk berbicara baik, yang dicapai berdasarkan bakat alam (talenta) dan keterampilan teknis (arts, techne). Dari pengertian diatas, dapat disimpulkan bahwa retorika adalah ilmu yang mengajarkan cara bertutur kata yang baik dan efektif untuk menghindari kesalah pahaman antara pembicara dan pendengarnya.

Tujuan retorika secara ringkas adalah persuasi, yaitu keyakinan pendengar akan kebenaran gagasan hal yang dibicarakan. Artinya, tujuan retorika adalah membina saling pengertian yang mengembangkan kerjasama dalam menumbuhkan kedamaian dalam kehidupan bermasyarakat melalui kegiatan bertutur (Abidin, 2013: 58). Retorika sebagai cabang ilmu yang digunakan dalam berkomunikasi sebagai seni berbicara dari mulai proses, persiapan, penataa, dan pelaksanaan tutur. Maka, ceramah, khutbah, dan pidato termasuk ke dalam kajian retorika.

Selanjutnya, Yusuf Zainal Abidin menjelaskan tujuan retorika kaitannya dengan dakwah yang penting adalah "memengaruhi audiens". Hal ini karena dalam berdakwah dibutuhkan teknik-teknik yang mampu memeberikan pengaruh efektif kepada khalayak masyarakat sebagai objek dakwah (al-mand'uu).

Fungsi retorika adalah membimbing penutur mengambil keputusan yang tepat, memahami masalah kejiwaan orang-orang yang akan dan sedang dihadapi, menemukan ulasan yang baik, dan mempertahankan diri serta mempertahankan kebenaran dengan alasan yang masuk akal (Abidin, 2013: 58) 
Sedangkan pengertian dakwah adalah memanggil, menyeru, menegaskan, atau membela sesuatu, perbuatan, ataupun perkataan untuk menarik manusia kepada sesuatu serta memohon dan meminta (Subandi et al, 2015: 15) Berdasarkan makna bahasa tersebut, dakwah berarti upaya memanggil, menyeru, dan mengajak manusia menuju jalan Allah agar terhindar dari kesesatan. Sehingga manusia menjadi seorang yang bertakwa.

Sedangkan yang dimaksud ajakan kepada Allah berarti ajakan kepada agama-Nya, yaitu al-Islam. Pemahaman ini sejalan dengan surah ali imran (3): 19

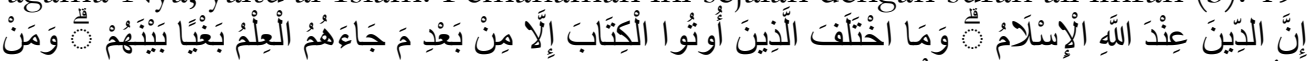

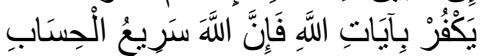

"Sesungguhnya Agama di sisi Allah ialah islam. Orang-orang yang telah diberi kitab tidaklah berselisih, kecuali setelah mereka memperoleh ilmu, karena kedengkian diantara mereka. Siapa yang ingkar terhadap ayat-ayat Allah, maka sugguh, Allah sangat cepat perhitungannya" (kementerian Agama RI, 2011: 52)

Perintah Allah untuk berdakwah kepada Islam terdapat dalam Al Quran Surah Ali Imran ayat 104:

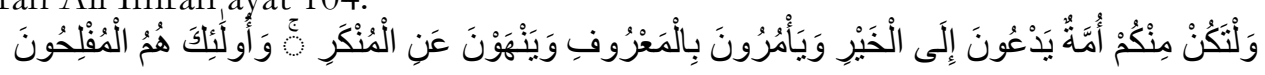

"Dan hendaklah diantara kamu ada segolongan orang yang menyeru kepada kebajikan, menyuruh (berbuat) yang makruf dan mencegah dari yang mungkar. Dan mereka itulah orang-orang beruntung" (Kementerian Agama RI, 2011: 63).

Secara terminologi, kata dakwah dapat didefinisikan sebagai ajakan kepada umat manusia menuju jalan Allah, baik secara lisan, tulisan, maupun perbuatan, derngan tujuan agar mereka mendapatkan petunjuk sehingga mampu merasakan kebahagiaan dalam hidupnya, baik di dunia maupun akhirat (Tajiri, 2015: 16).

Landasan umum bentuk metode dakwah adalah Al-Quran, terutama bentuk-bentuk metode dakwah, sebagaimana terdapat dalam Alquran Surah AnNahl (16): 125. Di dalamnya dijelaskan terdapat tiga metode dakwah yang disesuaikan dengan kondisi objek dakwah, yaitu hikmah, maw'izhah hasanah, dan muajadalah (Sukayat, 2015: 30).

Dari definisi retorika dan dakwah tersebut dapat disimpulkan bahwa retorika dakwah adalah keterampilan menyampaikan ajaran Islam secara lisan untuk memberikan pemahaman yang benar kepada kaum muslim, agar mereka dapat dengan mudah menerima seruan dakwah Islam. Dengan kata lain, retorika dakwah dapat dimaknai sebagai pidato atau ceramah yang berisikan pesan dakwah, yaitu ajakan ke jalan Tuhan (sabili rabbi) yang mengacu pada pengertian dakwah dalam Alquran surat An-nahl ayat 125 (Abidin, 2013: 132).

Tujuan retorika dalam kaitannya dengan dakwah yang paling penting adalah "memengaruhi audiens". Hal ini karena dalam berdakwah dibutuhkan 
Retorika dakwah ustadz Handy Bonny

teknik-teknik yang mampu memberikan pengaruh efektif kepada khalayak masyarakat sebagai objek dakwah (al-mad'uu). Di antaranya dengan menggunakan retorika ampuh jitu untuk memengaruhi orang lain agar membenarkan dan mengikuti apa yang diserunya. Sebagaimana dakwah adalah sarana komunikasi menghubungkan, memberikan, menyerahkan segala gagasan, cita-cita, dan rencana kepada orang lain dengan motif menyebarkan kebenaran sejati (Abidin, 2013: 133).

\section{HASIL DAN PEMBAHASAN}

Penelitian ini dilakukan untuk mengetahui bagaimana gaya bahasa, isi materi khitobah, diksi yang digunakan dalam khitobah, dan ekspresi khitobah yangdilakukan oleh Ustadz Handy Bonny. Kemudian dilakukan penelitian dari hasil mengikuti kegiatan dakwahnya dan menganalisis beberapa rekaman video ceramah Ustadz Handy Bonny. Setelah itu, didapatkan hasil bagaimana cara Ustadz Handy Bonny dalam menggunakan gaya bahasa, menggunakan diksi, intonasi, dan penyampaian gagasan retorika ketika beliau menyampaikan dakwahnya. Menyikapi hal itu, dapat dilihat dalam uraian dibawah ini:

\section{Penggunaan Gaya Bahasa dalam Khitobah Ustadz Handy Bonny}

Berikut adalah penjelasan Yusuf Zainal Abidin tentang gaya bahasa, gaya bahasa adalah cara pengungkapan pikiran melalui bahasa secara khas yang memperlihatkan jiwa dan kepribadian pengarang. Pada hakikatnya, gaya bahasa merupakan teknik pemilihan ungkapan kebahasaan yang dianggap dapat mewakili sesuatu yang akan disampaikan atau diungkapakan.

Ustadz Handy Bonny sering menggunakan gaya bahasa perbandingan mencakup: metafora, perumpamaan, gaya bahasa penegasan mencakup: litotes, pleonasme, gaya bahasa perulangan mencakup: alitersi, gaya bahasa kiasan mencakup hipalase. Bahasa yang digunakan oleh beliau pada saat melakukan ceramah adalah bahasa indonesia dan bahasa sunda, disesuaikan dengan kondisi jamaah yang dihadapinya. Berikut ini adalah pengertian gaya bahasa:

Tabel 1: Beberapa Macam Gaya Bahasa

\begin{tabular}{|l|l|l|l|}
\hline No & Gaya Bahasa & Pengertian \\
\hline 1. & Majas Pleonasme & $\begin{array}{l}\text { Gaya bahasa untuk memperjelas maksud dengan } \\
\text { menggunakan kata berulang dan maknanya sudah } \\
\text { Dikandung oleh kata yang mendahului. }\end{array}$ \\
\hline 2. & Majas Hiperbola & $\begin{array}{l}\text { Gaya bahasa untuk menggambarkan keadaaan } \\
\text { secara berlebihan. }\end{array}$ \\
\hline 3. & Majas Litotes & $\begin{array}{l}\text { Gaya bahasa untuk melukiskan hal untuk } \\
\text { merendeahkan diri }\end{array}$ \\
\hline 4. & Majas Repitisi & Gaya bahasa untuk mengulang kata tertentu \\
\hline
\end{tabular}

Tabligh: Jurnal Komunikasi dan Penyiaran Islam Vol. 3 No. 2 (2018) 172-189 


\begin{tabular}{|l|l|l|}
\hline & & beberapa kali. \\
\hline 5. & Majas Metafora & $\begin{array}{l}\text { Gaya bahasa yang membandingkan suatu benda } \\
\text { dengan benda lain. }\end{array}$ \\
\hline 6. & $\begin{array}{l}\text { Majas } \\
\text { Personifikasi }\end{array}$ & $\begin{array}{l}\text { Gaya bahasa yang melukiskan benda mati yang } \\
\text { diungkapkan seperti manusia. }\end{array}$ \\
\hline 7. & Majas Ironi & $\begin{array}{l}\text { Gaya bahasa sindiran yang paling halus, kadang } \\
\text { yang disindir tidak terasa }\end{array}$ \\
\hline 8. & Sinisme & Gaya bahas sindiran yang kasar \\
\hline 9. & Sarkasme & $\begin{array}{l}\text { Gaya bahasa sindiran yang paling kasar sehingga } \\
\text { sangat menyakitkan hati bagi orang yang disindir }\end{array}$ \\
\hline 10. & Eufisme & $\begin{array}{l}\text { Gaya bahasa yang menggantikan kata yang lebih } \\
\text { halus sehingga lebih sopan. }\end{array}$ \\
\hline 11. & Metonimia & $\begin{array}{l}\text { Gaya bahasa yang menggunakan benda yang } \\
\text { dimaksud dengan sebuah nama (merk dagang). }\end{array}$ \\
\hline 12. & Perumpamaan & $\begin{array}{l}\text { Gaya bahasa yang mengungkapkan pernyataan } \\
\text { dengan membandingkan du hal yang berbeda dan } \\
\text { menyimpulkan dari dua pernyataan tersebut. }\end{array}$ \\
\hline 13. & Aliterasi & $\begin{array}{l}\text { Gaya bahasa pengulangan kata yang sama dan } \\
\text { terdapat didalam satu pernyataan. }\end{array}$ \\
\hline 14. & Retorik & $\begin{array}{l}\text { Gaya bahasa berupa kalimat pertanyaan yang tidak } \\
\text { perlu untuk dijawab. }\end{array}$ \\
\hline 15. & Anti klimaks & $\begin{array}{l}\text { Gaya bahasa yang menyatakan kalimat yang } \\
\text { semakin menurun. }\end{array}$ \\
\hline
\end{tabular}

Pertama, gaya bahasa perbandingan beberapa macam gaya bahasa di atas memberikan pemahaman untuk mengklasifikasikan gaya bahasa dalam retorika yang digunakan Usatdz Handy Bonny. Seperti pada khitobahnya dengan tema quota usia gak bisa dibeli.

Perlu diketahui oleh ukhti semua pada sore hari ini bahwa ikhwan yang ada disini limited edition rebutan para ukhti yang ada di Indonesiabukan hanya jogya karena jepang sudah kekurangan populasi laki-laki mereka lebih menyukai pria Indonesiakarena laki-laki Indonesiaterlihat seperti sawo matang ada yang busuk lebih maco gitu kalau laki-laki yang item apalagi yang tangannya belang, apalagi yang keningnya hitam itu sujudnya bukan tangannya dulu tapi langsung jeger jidatnya, enggak bercanda (kutipan video tanggal 26 April 2018).

Dari penggalan paragraf di atas, terdapat kalimat yang termasuk ke dalam gaya bahasa metafora. Dikarena pada pembahasan di atas, dalam khitobahnya Ustadz Handy Bonny menggunakan gaya bahasa yang membandingkan.

Kedua, gaya bahasa selanjutnya yang digunakan oleh Ustadz Handy Bonny 
Retorika dakwah ustadz Handy Bonny

adalah gaya bahasa perumpamaan. Penggunaan gaya bahasa ini Seperti pada khitobahnya dibawah ini dengan tema aku mau kamu:

Orang yang tidak taat kepada Allah punya agenda buruk, orang yang taat kepada Allah punya agenda baiknya sama-sama berjuang, tapi beda perjuangannya. Apakah orang dugem, mohon maaf gak ada perjuangannya? Ada perjuangan brother. Bangun tengah malam pake baju yang paling seksi, uang disiapkan, parfum yang terbaik, pakean terbaik, berangkat tengah malam. Orang beriman beda perjuangannya bangun tengah malam, repot bangun tengah itu wah alarmnya (kutipan video youtube 8 April 2018).

Penggalan kalimat di atas termasuk ke dalam gaya bahasa perumpamaan. Karena pada khitobahnya tersebut, Ustadz Handy Bonny menggunakan gaya bahasa perbandingan persamaan, antara satu perumapamaan dengan perumpamaan yang lain. Dan perumapamaan tersebut berbeda maknanya. Hali ini ia lakukan untuk memberikan contoh masalah kepada jamaah.

Ketiga, gaya bahasa litotes tidak hanya gaya bahasa perumpamaan saja, Ustadz Handy Bonny juga menggunakan gaya bahasa litotes dalam menyampaikan khitobahnya. Gaya bahasa litotes adalah gaya bahasa yang dipakai untuk menyatakan hal sekecil-kecilnya untuk merendahkan diri. Penggunaan gaya bahasa ini terlihat diantaranya, dalam penggalan khitobah yang disampaikannya yaitu:

Maka saya dari Bandung datang sebagai yang hina dina untuk bercerita, berbagi pengalaman dalam medan dakwah, ada seorang ulama bernama malik bin dinar merupakan seorang ulama yang dalam majelis dia pernah mengatakan tidak ada stupun kemaksiatan yang tidak pernah aku lakukan tidak ada satu kemaksiatanpun yang tidak pernah aku lakukan senantiasa bermaksiat kepada Allah Swt sampai akhirnya ia bertaubat dan bersungguh-sungguh di jalan Allah dan sampai berikutnya beliau menjadi ulama yang paling termasyhur di kota Bashroh pada saat itu (video youtube 26 April 2018 dengan tema Quota usia gak bisa dibeli).

Gaya bahasa Ustadz Handy Bonny di atas menggunakan litotes peristiwa zaman dahulu Kisah ulama Malik bin Dinar. Dengan ia merendahkan diri sebagai seseorang yang hina dihadapan jamaah maka akan terjalin rasa persamaan antara mubaligh dan mubalagh.

Keempat, gaya bahasa selanjutnya yang digunakan oleh Ustadz Handy Bonny adalah gaya bahasa pleonasme. Gaya bahasa ini digunakan untuk memperjelas maksud dari suatu pernyataan. Dengan menggunakan kata berulang, tetapi maknanya tetap sama dengan kata sebelumnya. Seperti pada penggalan khitobahnya dengan tema Quota usia gak bisa dibeli:

Ketahuilah ukhti berbahagialah karena diantara kita pada sore hari ini hadir 
pria yang sanggup mencintai apa adanya bukan ada apanya kalaupun ada apanya hanya pancaran keimanan yang ada pada dirimu ukhti ia yang sanggup menjagamu, ia yang sanggup memberikan kenyamanan kepadamu sehingga engkau akan mengatakan laki-laki semua sama. Tidak kami berbeda, kami mencintaimu dengan tulus dan kami akan membingmu sampai jannah Allah Swt (video youtube Teras dakwah 26 April 2018)

Dari paragraf di atas Ustadz Handy Bonny menggunakan gaya bahasa pleonasme dengan memberikan penegasan kepada jamaah perempuan "pada sore hari ini hadir pria yang sanggup mecintai apa adanya bukan ada apanya" ini menunujukan ceramam yang disampaikan memberikan makna penegasan dengan mengulang kata tanpa merubah makna yang disampaikan Ustadz Handy Bonny.

Kelima, gaya gaya bahasa aliterasi. Dalam menyampaikan khitobah, Seringkali Ustadz Handy Bonny mengulang kata-kata yang digunakannya. Melakukan pengulangan kata dalam satu kalimat merupakan gaya bahasa aliterasi. Gaya bahasa aliterasi termasuk ke dalam gaya bahasa perulangan. Hal ini bisa temukan dalam penggalan video ceramahnya pada tangaal 24 Januari 2018 dengan hijrah. "Ini direkam oleh kamera dan aku bisa melihatnya nanti tayangannya maka ketika segala sesuatu sadar di rekam au ati-ati dalam berbicara, hati-hati dalam berperilaku, hati-hati dalam berpenampilan".

Pada penggalan kalimat di atas terdapat pengulangan kata "ati-ati dan hatihati". Sehingga kalimat di atas termasuk kedalam gaya bahasa perulangan aliterasi. Gaya bahasa aliterasi juga terdapat pada penggalan ceramahnya yang lain, pada tanggal 18 januari 2018 dengan tema hijrah. "Senengnya temenan sama orang beriman, dia senantiasa mengingatkan kita dalam ketaatan dan kita dilatih untuk berbicara. Sehingga tumbuh nilai-nilai kesadaran dalam diri kita untuk senantiasa memenuhi panggilan dari Allah Swt.

Gaya bahasa aliterasi pada kalimat di atas yang dapat ditemukan adalah pengulangan kata "nilai-nilai". Berikutnya, gaya bahasa aliterasi ditemukan pada khitobah Handy Bonny yang lain dalam kutipan video pada tanggal 8 April 2018 dengan tema Aku mau kamu yaitu ditemukan pengulangan kata sama-sama. "Orang yang taat kepada Allah punya agenda baiknya sama-sama berjuang tapi beda perjuangannya".

Dari penggalan khitobah handy bonny yang lainnya juga ditemukan kalimat yang menggunakan gaya bahasa alitersi. Dalam kutipan video Pada tanggal 26 April 2018 dengan tema quota usia gak bisa dibeli "Izinkan kang Bonny berbagi cerita, berbagi rasa, berbagi cinta buat rekan-rekan di jogja yang penuh dengan cinta insyaAllah walaupun ia belum mendapatkan seseorang yang mendampingi hidupnya".

Keenam, Gaya Bahasa Kiasan Hipalase. Gaya bahasa selanjutnya yang digunakan oleh Ustadz Handy Bonny adalah gaya hipalase. Yaitu gaya bahasa 
Retorika dakwah ustadz Handy Bonny

yang menerangkan satu kata, tetapi kata tersebut dimaksudkan untuk memberikan penjelasan kata yang lain. Gaya bahasa hipalase dapat ditemukan pada penggalan khitobah Handy Bonny pada tanggal 26 April 2018 dengan tema quota usia gak bisa dibeli "Maka kata Rasulullah sesungguhnya kebahagiaan dunia yang paling terbaik adalah usia dan Allah berikan al inabah (keadaan untuk bertaubat kepada Allah ) surga tempat orang rest and goodnes (berlomba dalam kebaikan)".

Dari paragraf di atas, Ustadz Handy Bonny menggunakan gaya bahasa hipalase, yaitu kata "al inaabab" kemudian ia dijelaskan lagi dengan kata "keadaan untuk bertaubat kepada Allah". Ustadz Handy Bonny memberikan penjelasan dengan menggunakan kata "keadaan untuk bertaubat". Hal tersebut merupakan kata sederhana yang mudah dipahami dari pada kata "al inabab".

Setelah dipaparkan di atas, beberapa gaya bahasa yang digunakan oleh Ustadz Handy Bonny adalah gaya bahasa metafora, gaya bahasa litotes, gaya bahasa pleonasme, gaya bahasa perumpamaan, bahasa alitersi, dan gaya bahasa hipalase. Enam gaya bahasa tersebut digunakan oleh Ustadz Handy Bonny dalam setiap kali menyampaikan ceramahnya.

Setelah dipaparkan di atas, beberapa gaya bahasa yang digunakan oleh Ustadz Handy Bonny adalah gaya bahasa metafora, gaya bahasa litotes, gaya bahasa pleonasme, gaya bahasa perumpamaan, bahasa alitersi, dan gaya bahasa hipalase. Enam gaya bahasa tersebut digunakan oleh Ustadz Handy Bonny dalam setiap kali menyampaikan ceramahnya.

Namun dari keenam gaya bahasa yang sering digunakan Ustadz Handy Bonny, ia lebih sering menggunakan gaya bahasa perumpamaan dan gaya Bahasa aliterasi. Gaya bahasa perumpamaan gaya bahasa yang membandingkan suatu kata dengan kata lainnya, tetapi dianggap mempunyai sifat sama atau mirip dalam suatu peristiwa. Kemudian gaya bahasa aliterasi merupakan gaya bahasa yang mengulang-ngulang kata pertama pada kata berikutnya, hal ini terdapat dalam setiap ceramah yang disampaikan handy bonny. Dua gaya bahasa tersebut yakni gaya bahasa perumpamaan dan gaya bahasa aliterasi lebih sering digunakan dalam khitobahnya Ustadz Handy Bonny. Karena dari sekian banyak ceramah yang ia lakukan tidak pernah meninggalkan suatu gaya bahasa perumpamaan dan perulangan.

Sebagai contoh, ia sering menggunakan kalimat "lebih romantis mana yang pacaran dan yang sudah nikah". Di dalam setiap khitobah yang handy bonny sampaikan dihadapan kaum muda, ia lebih sering menggunakan gaya perumpamaan romantisme orang yang belum menikah dan telah menikah. Hal ini berguna untuk menjelaskan kepada jamaah tentang permasalahan zaman sekarang. Karena setelah menikah, romantisme antara pasangannya jadi berkurang.

Dari semua contoh bahasa yang digunakan di atas, selanjutnya peneliti 
menganalisis bahasa handy bonny dalam menyampaikan khitobahnya. Maka akan didapatkan hasil berupa bahasa yang digunakan oleh Ustadz Handy Bonny. Analisis gaya bahasa Ustadz Handy Bonny yaitu bahasa yang digunakan jelas artikulasinya, menggunakan bahasa yang baik dan sopan, mengguanakan gaya bertanya dan menjawab kepada pendengar, menggunakan bahasa yang menarik perhatian orang dengan suara yang jelas, memberikan semangat dan imbauan.

\section{Penggunaan Diksi Dalam Khitobah Ustadz Handy Bonny}

Diksi atau pilihan kata yang tepat dan selaras digunakan untuk mengungkapkan atau menyatakan kata-kata yang dipakai untuk mengungkapkan suatu gagasan atau cerita. Kata yang tepat akan membantu seseorangmengungkapkan dengan tepat apa yang ingin disampaikannya, baik lisan maupun tulisan. Disamping itu, pemilihan kata itu harus pula sesuai dengan situasi dan tempat penggunaan katakata itu (Arifin et al, 2010: 28).

Dengan menggunakan diksi yang baik, maka kata-kata yang keluar dari seorang pembicara dapat dipahami oleh pendengar. Oleh karena itu penggunaan kata-kata dalam khitobah berguna untuk mempengaruhi dan meyakinkan pendengar. Sehingga tercipta komunikasi yang efektif dan efissien.

Pada pembahasan ini, diksi yang dimaksud adalah kefasihan Ustadz Handy Bonny ketika mengucapkan kata dan kalimat yang sesuai dengan bahasa yang digunakan. Pengucapan kata yang jelas dan lugas tentu berpengaruh kepada maksud dan tujuan dari materi yang disampaikan.

Pada saat menyampaikan materi ceramah, seorang Ustadz tak lepas dari melafalkan ayat Al Quran dan hadis. Maka diperlukan makhraj yang benar dan jelas untuk melafalkan dalam setiap huruf-huruf arab. Karena melafalkan Al Quran dan hadis menggunakan makhraj yang benar, akan menjadikan penunjang seorang Ustadz dalam menyampaikan ceramahnya. Selain itu juga, untuk meyakinkan pendengar dan sekaligus menjadi daya tarik seorang pendakwah dalam menyampaikan setiap khitobahnya. Maka kefasihan dalam melafalkan ayat Alquran dan hadis perlu diperhatikan oleh setiap Ustadz.

Ustadz Handy Bonny menggunakan diksi dengan jelas, fasih, dan lugas pada waktu menyampaikan khitobahnya. Salah satu contoh ialah ketika Handy Bonny melafalkan ayat Alquran dan hadist yang menjadi kebiasaannya diucapkan dengan fasih. Hal ini dapat dilihat dari penggalan video khitobahnya

pada tanggal 20 November 2018 dengan tema Indahnya menikah beliau membacakan ayat Alquran seperti dibawah ini:

Yang pertama menyatukan empat mata menjadi satu fisik, menyatukan empat langkah kaki menjadi satu tujuan untuk sampai pada tujuan, menyatukan dua hati menjadi satu keyakinan. 


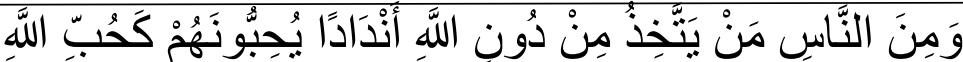

"Dan diantara manusia ada orang-orang yang menyembah tandingantandingan selain Allah, mereka mencintainya sebagaimana mereka mencintai Allah" Quran Al baqarah 165.

Yang paling sama kita Allah, yang paling sayang sama kita Allah, yang paling perhatian sama kita Allah, kenapa kita memilih perhatian dari orang lain?.

Dari paragraf di atas Ustadz Handy Bonny melantunkan penggalan ayat Alquran surah Al Baqarah ayat 165. Hal ini ia lakukan karena menyesuaikan dengan kebutuhan ceramahnya yang disampaikan. Sehingga jamaah yang mendengarnya dapat memahami maksud dan tujuan yang disampaikan Ustadz Bonny. Ketika Handy Bonny melantunkan ayat suci Al Quran, beliau mengucapkan ayat Al Quran dengan makhrajnya jelas dan tidak tergesa-gesa.

Ustadz Handy Bonny juga menggunakan kata-kata yang sederhana dan mudah dipahami jamaah yang mendengarnya. Sehingga jamaah yang hadir dalam setiap kajian rutinnya selalu banyak, karena ucapannya nyaman untuk didengar. Diksi yang sederhana diiringi intonasi yang baik dan selalu menyesuaikan dengan kondisi jamaah yang dihadapi, hal ini membuat Ustadz Handy Bonny selalu dinantikan jammam nya dalam setiap kajian.

Dibawah ini merupakan contoh kata sederhana dan memberikan penjelasan yang mudah dipahami jamaah yang mendengarnya. Ketika Handy Bonny menyampaikan khitobahnya dalam penggalan video pada tanggal 20 November 2018 dengan tema indahnya menikah:

Ketika sudah menikah ternyata isteri membeli kucing dalam karung, ketika lagi mengenalnya dengar adzan saya bilang, maaf ukhti saya mau sholat dulu, padahal dimasjid saya gak sholat brother, ana gak pernah sholat. Maka ketika sudah nikah masyaallah, subhanallah, isteri lagi sholat saya tendang, isteri lagi ngaji saya larang-larang karena saya dulu ateis. Gak percaya sama yang begituan-begituan cuman saya semangat dapat ngedapetin wanita itu aja gitu aja (video youtube cvs production 20 November 2018).

Kalimat di atas begitu mudah dipahami, walaupun pada awal pembicaraannya dengan suatu istilah. Tetapi pada kalimat selanjutnya, Handy Bonny memberikan penjelasan yang cepat dan cermat dengan menggunakan kata-kata yang sederhana. Sehingga maknanya dapat dipahami jamaah dengan jelas.

Kemudian dapat dilihat dari contoh penggalan khitobah yang lain, ketika Ustadz Handy Bonny menggunakan kata-kata sederhana tanpa harus ada penjelasan lagi kepada para jamaahnya. Di bawah merupakan penggalan khitobah Handy Bonny yang menggunakan kata sederhana dengan menceritakan kisah hidupnya ketika memperjuangkan jodoh. Pada tanggal 24 Januari 2018 dengan tema hijrah: 
Dulu saya nikah tahun 2012 brother. Itu dulu kemudian saya datengin. Wah ini cewe cantik banget, kemudian saya lihat oh sering ngaji. Datengin sama saya di masjid DT, begitu turun beres dari kajian saya datengin. Assalamualaikum ukhti boleh kenalan gak? Itu ternyata temen SMP aku isteri aku tuh. Ah kata dia maaf ya Bon aku gak bisa ketemuan sama kamu (video pro you channel 24 Januari 2018).

MasyaAllah susah banget ngedeketin cewe sholehah itu, sampe kata dia, kalau serius datengin rumah aku, dimana? dipanjalu Ciamis. Didatengin sama kang Bonny pake elf duduk di depan, elf itu bawanya luar biasa brother, ana udah kaya mau mati dibawa elf itu. Sampai di panjalu kang Bonny turun ketemu rumah kakeknya. Ketika turun dari elf, ketika sampai rumah kakeknya, ini kisah nyata ya, kakeknya melihat saya. Keluar dari rumah ngeliat saya turun dari elf, kakeknya punya anjing diluar halaman, dipanggil anjingnya boni,boni,boni wah sama hahaha ini kesiapa ini? Boniboni nama anjingnya brother.

Pada paragraf di atas, pemilihan kata yang dilakukan Ustadz Handy Bonny begitu sederhana tanpa harus ada penjelasan lagi. Beliau juga memakai intonasi yang baik, suara tinggi dan rendahnya sesuai dengan alur cerita yang ia sampaikan. Sehingga cerita yang disampaikannya tidak membosankan. Walaupun Handy Bonny sering menceritakan kembali di tempat kajian yang lain, $\mathrm{Hal}$ ini membuat jamaahnya terhibur.

Hasil dari analisis pemilihan kata-kata yang dilakukan Ustadz Handy Bonny, dapat disimpulkan bahwa beliau menggunakan kata-kata yang jelas, lugas, dan tertata dengan baik. Tentusaja penggunaan kata yang sederhana dan kata yang diulang-ulang dapat mudah dipahami oleh jamaah yang mendengarnya. Tetapi kekurangannya terkadang penyampaian materi Ustadz Handy Bonny sedikit tidak jelas karena artikulasi terlalu cepat terutama dalam menyampaikan bahasa Arab.

\section{Intonasi dalam Khitobah Ustadz Handy Bonny}

Intonasi adalah tekanan-tekanan suara yang diucapkan oleh seseorang ketika sedang berbicara. Dalam menyampaikan materinya, Ustadz Handy Bonny menggunakan intonasi yang bervariasi disesuaikan dengan materi yang disampaikannya. Intonasi yang digunakannya dimulai dari suara yang rendah sampai pada suara yang tinggi.

Rendah tingginya nada suara dan cara pengucapannya akan menunjang seorang mubaligh dalam menyampaikan materinya. Dengan menggunakan intonasi yang baik, maka jamaah yang mendengar akan terkesan dan tertarik untuk menyimak khitobah yang disampaikan seorang mubaligh. Penekanan suara yang dilakukan oleh Ustadz Handy Bonny mampu menarik perhatian pendengarnya. Dengan hal ini maka jamaah yang mendengarnya akan paham 
Retorika dakwah ustadz Handy Bonnv

terhadap materi yang disampaikannya. Karena nyaman dan fokus terhadap materi yang disampaikan Ustadz Handy Bonny.

Ustadz Handy Bonny biasanya memakai intonasi yang rendah dan sedang pada saat pembukaan atau awal dari khitobahnya. Seperti dalam penggalan video khitobah Handy Bonny.

Mudah-mudahan yang hari ini berkumpul ditempat ini/ mendapatkan keridoan dari Allah Swt// Allah menaikan derajat kita/ Allah mengahpuskan dosa-dosa kita/ itu yang harus kita yakini// brother and sister fillah/ kalau kita gak yakin/ repot itu// perjuangan kita semuanya/ penuh dengan keluh kesah// dari jalan kesini/ wah macam-macam caranya// keringetnya/ panasnya/ semuanya jadi keluh kesah// tapi ketika inget sedang di jalan Allah/ keringet itu menjadi masya Allah// semoga keringet ini menjadi saksi ya Allah/ di yaumul akhir// ya Allah bocor ban ini/ semoga menjadi saksi// ya Allah udah panas/ keringetan dompet tipis/ jomblo ya Allah// semua yang menimpa dalam diri kita/ kita jadikan bentuk syukur kita/ kepada Allah Swt// (video youtube teras dakwah 26 April 2018).

Intonasi rendah dan sedang juga dapat ditemukan pada penggalan khitobah Ustadz Handy Bonny yang lainnya. Seperti dalam penggalan video khitobahnya di bawah ini dengan tema indahnya menikah.

Alhamdulillah/ pada kesempatan hari ini/ pada malam yang berbahagia ini/ kita dipertemukan/ di tempat yang insyaAllah senantiasa dimuliakan oleh Allah Swt// Mudah-mudahan ibu-ibu/ teteh-teteh/ aa-aa/ bapakbapak yang hadir/ pada malam hari ini// yang mengalami permasalahan dalam hidupnya/ Allah berikan kelancaran/ dan kemudahan// Yang malam hari ini lagi sakit/ Allah berikan kesembuhan// Yang malam hari ini keur loba hutang/ dilunasan sadayana// Tah aminna tarik/ loba teuing hutang na eta tah// enjing jatuh tempo geningan ibu/ ka inget-inget eta tah duuh// kalm teh Dini duuh ya Allah/ Insya Allah moal ngalaman teh Dini ya insya Allah// (video youtube cvs production 20 November 2018).

Pada kalimat di atas, Ustadz Handy Bonny menyampaikan pembukaan khitobah dengan menggunakan intonasi yang rendah dan sedang. Hal ini dapat dilihat ketika ia mengucapkan kata "mudah-mudahan". Penekanan kata tersebut tidak mungkin diucapkan dengan nada yang tinggi.

Ustadz Handy Bonny tidak hanya memakai intonasi rendah dan sedang saja. Beliau juga terkadang menggunakan intonasi yang tinggi dengan tekanantekanan yang jelas pada saat menyampaikan khitobahnya. Kemudian juga terdapat pernyataan dan pertanyaan di dalam khitobah tersebut. Seperti dalam penggalan video khitobah Handy Bonny pada tanggal 24 April 2018 dengan tema hijrah 
"Yang paling baik sama kita Allah/ yang paling sayang sama kita Allah/ yang paling perhatian sama kita Allah/ kenapa kita memilih perhatian dari orang lain?// kenapa kita merasa orang lain lebih sayang sama kita?/ mengapa kita mengharapkan jani-jani palsu/ yang diberi pacar kita?// mengapa kita mengharapkan balesan sms dari pacar kita?/ enggak//".

Intonasi yang tinggi juga digunakan Ustadz Handy Bonny ketika menjelaskan suatu permasalahan yang sedang trending pada saat ini. Seperti pada kalimat di bawah ini, beliau memberikan penjelasan hijrah yang diberi penakanan yang tinggi. Seperti pada penggalan khitobah Handy Bonny pada tanggal 24 Januari dengan tema hijrah "yang namanya hijrah// berproses/ berprogres// kalaupun banyak yang protes/ jangan dibawa setres/ jalani aja sampe beres/ biar sukses/ brother// berproses step by step/ sedikit demi sedikit// setahap demi setahap demi setahap/ kita perlu dilatih brother// bagaiamana cara melatih proses hijrah/ terus belajar//".

Pada kalimat di atas, Ustadz Handy Bonny menyampaikan khitobahnya dengan intonasi atau penekanan tinggi yang lugas. Hal ini dapat dilihat ketika beliau tak henti-hentinya menjelaskan arti dari kata "hijrah". Beliau juga menggunakan pilihan kata dengan ritma yang bagus. Sehingga membuat jamaah yang mendengarnya tidak bosan. Tujuan dari kalimat di atas yaitu jamaah yang mendengarnya dapat memahami makna dari kata hijrah yang di sampaikan Ustadz Handy Bonny. Karena beliau telah merasakan indahnya perjalanan hijrah yang dilaluinya dimulai dari titik nol sampai sekarang menjadi seorang pendakwah.

\section{Penyampaian Gagasan Retorika Dakwah Ustadz Handy Bonny}

Penyampaian gagasan biasanya mencakup beberapa perilaku seperti kontak mata, tanda vocal, ejaan kejelasan pengucapan, dialek, gerak tubuh, dan penampilan fisik. Penyamapaian yang efektif mendukung kata-kata pembiacara dan membantu mengurangi ketegangan pembicara (West, Richard: 2008).

Ustadz Handy Bonny mempunyai ciri khas tersendiri yang nampak berbeda dari seorang dai biasanya. Dalam menyampaikan ceramahnya, beliau selalu semangat dan ekspresif. Itulah yang membuat jamaah yang mendengarnya tidak bosan, dan selalu semangat ketika Ustadz Handy Bonny menyampaikan khitobahnya. Ekspresi yang diperlihatkan Ustadz Handy Bonny menggunakan gerak tubuh, terutama menggerakan tangan dan mimik wajahnya. Beliau sering menggerakkan tubuhnya walaupun menggunakan kursi pada saat melakukan ceramahnya. Seperti halnya mencotohkan seorang yang sedang romantisme dalam pacaran. Sehingga jamaah yang mendengar terhibur karena dari ekspresi wajah beliau memuncullkan humor tersendiri. 
Retorika dakwah ustadz Handy Bonny

Humor dalam berkhitobah dianggap perlu. Karena pada jaman sekarang madhu atau yang mendengar khitobah lebih menyukai seorang Ustadz dengan selera humor yang bagus. Hanya saja humor juga harus dibatasi. jika terlalu sering menggunakannya terkesan tidak bersungguh-sungguh atau serius dalam menyampaikan khitobahnya. Ustadz Handy Bonny selalu membawakan ceramahnya dengan santai dan selalu menyelipkan humornya melalui ekspresi gerak tubuh terutama wajahnya. Dengan menggunakan contoh atau ilustrasi yang sedang kekinian pada jaman sekarang.

Sehingga madhu nya mudah dalam memahami materi yang disampaikan oleh beliau. Jika ceramah pada jaman sekarang tidak diselipkan humor, biasanya jamaah yang mendengar khitobah terutama dikalangan remaja akan merasa jenuh dan tidak nyaman berada di tempat kajian. Humor juga digunakan untuk menghidupkan suasana dakwah dalam suatu penyampaian materi. Supaya jamaah terpancing untuk mendengarkan isi materi ceramah yang disampaikan oleh seorang mubaligh.

Selanjutnya, Handy Bonny termasuk penceramah yang dikenal sebagai Ustadz gaul dikalangan remaja. Beliau menyampaikan ceramah dengan energik dan tidak monoton. Hal ini bisa dilihat dari beberapa video ceramah yang dianalisis. Dalam penyampaian ceramahnya lebih banyak membahas yang berkenaan dengan fenomena jaman sekarang. Kemudian juga memberi contoh dengan kondisi kehidupan seorang remaja pada jaman sekarang. Hal inilah yang menarik minat para remaja muslim untuk mengikuti ceramahnya, walaupun dalam kegiatan yang bukan khusus untuk remaja. Salah satu contoh yaitu, Ustadz Handy Bonny berkhitobah dalam pengajian ibu-ibu masjid Al Hasan bumi panyawangan. Dalam setiap kegiatan dakwahnya, Ustadz Handy Bonny selalu berpenampilan sederhana dan mengikuti tren remaja masa kini. Seperti halnya dalam berpakaian, beliau memakai pakaian yang kekinian sedang tren dikalangan remaja. Kadang juga, beliau memakai kupluk ataupun topi. Beliau berpakaian selalu menyesuaikan dengan jamaah yang dihadapinya. Sehingga terlihat lebih santai pada saat menyampaikan ceramahnya.

Ustadz Handy Bonny menggunakan jenis retorika dakwah ektemporer. Atau jenis retorika yang tidak menggunakan teks ataupun catatan. Karena beliau belum pernah terlihat sekalipun dalam menyampaikan cermahnya memakai teks atau catatan. Model retorika ektemporer adalah jenis retorika yang banyak digunakan oleh para mubaligh dalam menyampaikan khitobahnya.

Dari seluruh pembahasan di atas, maka hasil dari penelitian mengenai gaya retorika Ustadz Handy Bonny akan dibandingkan dengan teori yang digunakan oleh Harold Laswell. Menurut Harold Laswell, komunikasi dapat terwujud melalui who (siapa/sumber), says what (pesan apa yang disampaikan), in which channel (saluran yang digunakan), to whom (siapa penerima pesan), with what effect ( dampak apa yang terjadi). 
Ustadz Handy Bonny menggunakan lima unsur komunikasi teori Harold laswell. Karena dakwah yang dilakukannya ditunjang ditunjang oleh seluruh unsur komunikasi tersebut. sehingga hal inilah yang menjadi kekuatan Handy Bonny dalam menyampaikan dakwahnya, terutama dikalangan remaja dan pemuda.

\section{PENUTUP}

Berdasarkan hasil penelitian dari pembahasan skripsi ini tentang retorika dakwah Ustadz Handy Bonny, dapat disimpulkan bahwa:

Ustadz Handy Bonny sering menggunakan gaya bahasa perbandingan mencakup: metafora, perumpamaan, gaya bahasa penegasan mencakup: litotes, pleonasme, gaya bahasa perulangan mencakup: alitersi, gaya bahasa kiasan mencakup hipalase.

Bahasa yang digunakan oleh beliau pada saat melakukan ceramah adalah bahasa indonesia dan bahasa sunda, disesuaikan dengan kondisi jamaah yang dihadapinya.Pemilhan kata atau diksi yang digunakan Ustadz Handy Bonny adalaha kata-kata sederhana dan gaul yang mudah dipahami bagi yang mendengarkannya.

Bahasa yang gaul ini menjadi ciri khas tersendiri bagi Ustadz Handy Bonny yang disesuikan dengan jamaah yang hadir, sehingga minat kaum muda untuk mengikuti dakwahnya begitu antusias. Naik turun atau tinggi rendahnya nada atau intonasi yang digunakan Ustadz Handy Bonny selalu menyesuaikan dengan materi yang disampaikannya dan disertai penekanan-penekanan suara yang tegas. Penghayatan dalam membawakan suatu materi menjadi lebih hidup karena penekanan suara antara tinggi dan rendah itu selalu sesuai.

Kategori pesan dakwah yang disampaikan Ustadz Handy Bonny banyak menyampaikan tentang hijrah yaitu meninggalkan semua keburukan menuju keadaan yang lebih baik agar mendapat rido allah Swt. Pada dasarnya, beliau adalah sosok seorang pendakwah yang pernah mengalami masa kelam, sehingga didalam menyampaikan pesan dakwah tentang hijrah beliau lebih paham dengan situasi kondisinya.

Saran,Berdasarkan hasil penelitian yang telah dilakukan, maka ada beberapa saran diantaranya:

Pertama, Harus semangat dan istiqamah dalam menyampaikan dakwah Islam. Figur Ustadz Handy Bonny merupakan sosok pendakwah muda yang professional dalam menyampaikan dakwah dikalangan remaja dan pemuda. Hal ini dibutuhkan oleh masyarakat dalm membina remaja dan pemuda.

Kedua, Kepada Ustadz Handy Bonny hendaknya menjaga keutuhan retorika dalam berdakwah. Seperti halnya menggunakan pilihan kata yang gaul juga jelas dan penekanan suara rendah dan suara tinggi yang selalu diikuti dengan gerakan tubuh. 
Retorika dakwah ustadz Handy Bonny

Ketiga, Janganlah berhenti menyampaikan dakwah sampai Allah memerintahkan untuk berhenti. Karena dakwah adalah tugas yang mulia yang disampaikan untuk menyadarkan umat islam dalam pemahan aqidah, syariat, muamalah, dan akhlak.

\section{DAFTAR PUSTAKA}

Abdullah. (2009). Retorika dan Dakwah Islam. Jurnal Dakwah Vol. X No. 1 Tahun 2009 .

Abidin, Y. Z. (2013). Pengantar Retorika. Bandung: CV Pustaka Setia.

Amin, S. M. (2008). Rekontruksi Pemikiran Dakwah Islam. Jakarta: Amzah.

Arifin, Z. \& Tasai, A. (2010). Cermat Berbahasa Indonesia. Jakarta: Akademika Pessindo

Linarwati, M. \& dkk. (2016). Studi Deskriptif Pelatihan dan Pengembangan Sumberdaya Manusia Serta Penggunaan Metode Behavioral Event Interview Dalam Merekerut Karyawan Baru di Bank. Mega Cabang Kudus. Journal of Management Vol.2 No.2 Maret Tahun 2016.

Muhtadi, A. S. (2013). Komunikasi Dakwah (teori, pendekatan, dan aplikasi)

Rakhmat, J. (2015). Retorika modern Pendekatan Praktis. Bandung: PT Rosda Karya.

Sukayat, T. (2015). Ilmu Dakwah Perspektif Filsafat Mabadi 'Asyarah. Bandung: Simbiosa Rekatama Media.

Tajiri, H. (2015). Etika dan Estetika Dakwah Persfektif Teologis, Filosofis, dan Praktis. Bandung: Simbiosa Rekatama Media.

West, R. \& Lynn H. T. (2008). Pengantar Teori Komunikasi (Analisis dan Aplikasi). Jakarta Selatan: Salemba Humanika. 